\title{
EXCHANGE RATE PASS-THROUGH TO DOMESTIC PRICES IN NAMIBIA: SVAR EVIDENCE
}

\author{
Johannes Sheefeni* \\ Nelson Mandela Metropolitan University \\ peyavali@gmail.com
}

Received: March 2013

\author{
Matthew Ocran\# \\ Nelson Mandela Metropolitan University \\ Matthew.ocran@nmmu.ac.za
}

Accepted: October 2013

\begin{abstract}
This article investigates exchange rate pass-through to domestic prices in Namibia. The study covers the period of 1993:01 - 2011:04, and employed the impulse response functions and variance decompositions obtained from a structural vector autoregressive model. The results from the impulse response functions show that there is a high and long-lasting effect from changes in exchange rates to inflation in Namibia, or high exchange rate pass-through into domestic inflation. The results from the forecast error variance decompositions also reflect that changes in the price level evolve endogenously with changes in the exchange rate. The results are in agreement with the findings of the impulse response functions regarding the significant effect of the exchange rate variable on domestic prices (inflation). The results confirm an incomplete pass-through, indicating that the purchasing power parity theory does not hold, with regard to the price level, in the context of Namibia.
\end{abstract}

Keywords

Exchange rate, Short-run, Pass-through, Inflation, Structural vector autoregressive, Impulse response, Namibia

*Dr JP Sheefeni, Department of Economics, Nelson Mandela Metropolitan University, South Africa.

\#Prof M Ocran is a professor in the Department of Economics, Nelson Mandela Metropolitan University, South Africa. 


\section{INTRODUCTION}

In a small open economy such as Namibia's, the exchange rate channel provides an important transmission avenue for monetary policy. It is for this reason that understanding the extent to which exchange rate alters relative prices is critical. In general, the literature on exchange rate pass-through refers to the effect of exchange rate changes on one of the following: (1) import and export prices, (2) consumer prices, (3) investments and (4) trade volumes (Wimalasuriya, 2005; Eckstein and Soffer, 2008). This article draws its primary interest from the effects of exchange rate changes on consumer prices. Furthermore, exchange rate pass-through is also critical to monetary policy design and exchange rate policies. It is important because it also serves as an indicator to economic agents in particular for the private sector.

The debate as to whether exchange rate changes have a significant impact on domestic prices has well-known important implications for macroeconomic policy design (Taylor, 2000). There are two major issues to be explained in this aspect. First, if the degree of pass-through is high, the exchange rate changes will change the relative prices of tradables and non-tradables, so that the adjustment in trade balances will be relatively quick. In particular, the imported goods will become expensive. However, if the pass-through is so high that it will induce expenditureswitching from imports to domestic goods, then external balances will be corrected in a few periods. On the contrary, if the degree of pass-through is low, then the impact of the exchange rate on the trade balance is minimal (Eckstein and Soffer, 2008). Due to these matters, investigating the dynamics and the determinants of exchange rate pass-through has become necessary in the context of monetary policy design, as well as investigating the role of exchange rate regime on domestic inflation.

The earliest theory linking the exchange rate and prices is the Law of One Price (LOOP). This law implies that there is full exchange rate pass-through. This law has been shown to be flawed, and, consequently, it has led to the generation of a large number of empirical studies. Accordingly, the objective of this article is to examine the effects of the pass-through effects of the exchange rate changes on domestic prices in Namibia. This article is divided into five sections. Following the introduction is the theoretical and empirical literature review on this channel presented in section two. Section three presents the methodology adopted in estimating the exchange rate channel. The discussion on the data and the results of the empirical analysis are presented in section four. Section five concludes the study.

\section{LITERATURE REVIEW}

The main theoretical basis for the concept of exchange rate pass-through is the LOOP and purchasing power parity (PPP). The LOOP states that identical products should sell for the same common-currency price in different countries. If the LOOP holds for all products between two countries then the absolute purchasing power parity theory of exchange rates would also be valid between the two respective countries. However, the assumptions for maintaining the strong version of PPP are very restrictive because of the following: firstly, there is instantaneous costless and frictionless arbitrage, and secondly the same goods enter the basket of goods with the same weight in every country (Eckstein \& Soffer, 2008:335).

Before proceeding any further, it is important to define exchange rate pass-through (ERPT). Goldberg and Knetter (1997) define ERPT as the percentage change in local currency import 
prices resulting from a one percentage change in the exchange rate between the exporting and the importing countries. Similarly, Menon (1994) defines exchange rate pass-through as the degree to which exchange rate changes are reflected in the destination currency prices of traded goods. The ERPT also refers to the effects of exchange rates on domestic inflation.

Exchange rate change which is not accompanied by a change in a local currency in the price of goods would be considered a divergence from the LOOP. It is expected that demand and supply mechanisms will bring about the necessary change in local prices in order to bring foreign and domestic prices back to the same level. If this is true then this assumption implies that exchange rate pass-through should be complete, and might be close to $100 \%$ in the very long run. The literature does discuss reasons as to why the LOOP and PPP do not actually hold, in other words why they are not actually observed. Some of these reasons will now be presented. First of all, even if the LOOP does hold, it should hold only for tradable goods, and even for these products there is a significant component of locally sold services. In general, the standard model based on the Ballassa-Samuelson hypothesis supports the view that a change in the exchange rate as a result of a productivity shock would not pass through to the price of nontradables, and thus would result in a change in the real exchange rate. An exchange rate change which results from a nominal shock due to monetary policy action would in the long run pass through to the prices of both sectors (Eckstein and Soffer, 2008:335).

Other reasons discussed in the literature are that the LOOP may not hold due to differences in taxation policy across countries, as well as trade barriers and transportation costs. Another reason has to do with the degree of competitiveness of different markets. If firms have some monopolistic power, they could 'price to market', and this could result in different prices in each market.

Since a $100 \%$ pass-through is rarely recorded in empirical studies, it is important to distinguish between pass-through to prices of imports and pass-through to all consumer prices. The former case would rely on the assumption of low non-tradable components which together with the theory would predict close to complete pass-through, and this is indeed often recorded. However, the focus is on the pass-through of changes in the exchange rate to all consumer prices (Eckstein and Soffer, 2008:335).

Dornbusch (1987) discussed the alternative to complete pass-through, the incomplete passthrough via models, by introducing the degree of market concentration, extent of product homogeneity and the relative market shares of domestic and foreign firms. This model shows that if there is oligopolistic competition, and/or import and domestic goods are imperfect substitutes, exchange rate pass-through can be less than unity, as firms strategically modify their pricing behaviour and consumers change their pattern of consumption to increase or decrease imported goods. In the same way Baldwin (1988), Dixit (1989) and Baldwin and Krugman (1989) also indicated that due to the irrevocable sunk costs firms are less likely to enter a market following a temporary and/or small exchange rate change. Depending on the large sunk costs, existing firms are also discouraged from leaving the market. Such firms may continue to serve the market without even covering its variable costs.

Other studies took the angle of new open economy macroeconomics, which deals with the responsiveness of consumer prices to exchange rates. These studies arose from the recent empirical evidence that argued that consumer prices are not much affected by nominal exchange rates (see Engel, 2002 and Obstfeld and Rogoff, 1996). On the other side, some recent studies emphasised the importance of macroeconomic conditions on exchange rate pass- 
through. For example, Taylor (2000) argues that the recent decline in pass-through or pricing power is due to the low inflation environment that has recently been achieved in many countries.

There are various empirical studies that have looked at the issue of ERPT. McCarthy (2000) presents a comprehensive study of exchange rate pass-through on the aggregate level for a number of industrialised countries. A VAR model was estimated using import, producer and consumer-price data from 1976 up until 1998, and the exchange rate pass-through to consumer prices was found to be modest. The rate of pass-through was also found to be positively correlated with the openness of the country as well with the persistence of exchange rate change, while negatively correlated with the volatility of the exchange rate.

McFarlane (2002) analysed the relationship between exchange rate and prices in Jamaica and how it evolved over the past twelve years. Monthly data for January 1990 to December 2001 was used in estimating a vector error correction model (VECM), impulse response function and variance decomposition. The results indicate that, in the long run, the exchange rate passthrough is 'complete'. However, the extent of the pass-through has slowed in recent years and is partially due to the shift to a tighter monetary policy regime and increased competition.

Sahminan (2002) estimated the exchange rate pass-through for three Southeast Asian countries, namely Thailand, Singapore and the Philippines. Time series of quarterly data from 1974:1 to 2000:3 for Thailand and Singapore, and from 1974:1 to 1991:4 for the Philippines were used. This study employed cointegration $(\mathrm{Cl})$ and the error correction model $(\varepsilon C M)$. The results of the cointegration analysis show that the long-run exchange rate pass-through into import prices in Thailand, Singapore, and the Philippines are $0.647,0.408$, and 1.433, respectively. The results of the error correction model show that, in the short run, exchange rate does not have significant effect on import prices in Thailand and Singapore, but has a significant negative effect in the Philippines. In Thailand and Singapore, in the short run, import prices are influenced by foreign price and foreign demand rather than by exchange rate.

In Turkey, Alper (2003) studied the determinants and the evolution of the exchange rate passthrough to domestic inflation in the Turkish economy. The study covered the period 1987-2003. In the analysis, single equation error correction models were used to estimate the exchange rate pass-through. Estimation results suggest that, like other emerging countries, the degree of exchange rate pass-through to domestic prices is high and the pass-through is completed in a very short time span. Estimation results also revealed that the main factors to account for high pass-through are the past currency crises and the high degree of openness of the economy. These factors create the ground for the indexation behaviour of agents. Although the abovementioned factors are the main determinants of the degree of exchange rate pass-through, the persistency and the volatility of exchange rates can significantly affect the short-run dynamics of the pass-through. The results imply that even if the pass-through slows down due to the changing pattern of exchange rates, to achieve the low and stable inflation in the long run, fundamental factors that exacerbate the link between exchange rates and prices should change.

Wimalasuriya (2005) examined exchange rate pass-through into prices in Sri Lanka. The study used two approaches in estimating the pass-through effect. First, pass-through into import prices was estimated with the use of a log-linear regression model. The results obtained suggest that exchange rate pass-through into import prices is around $50 \%$, that is to say, import prices increase by about $0.5 \%$ as a result of a $1 \%$ depreciation of the nominal effective exchange rate. Second, taking a vector autoregressive (VAR) approach, exchange rate pass-through into a set of prices in the 'pricing chain' was estimated. In this scenario, exchange rate pass-through to factor input prices, trade prices, wholesale producer prices and retail consumer prices were 
examined, with the assumption that changes in the exchange rate are due to shocks which are exogenous to the model. The results obtained for this model suggest that exchange rate passthrough into consumer prices is about $30 \%$, although pass-through into wholesale producer prices was found to be complete. The findings from the second model further suggest that changes in the exchange rate could have significant implications for the trade balance.

Using VAR analysis on monthly data for 1993:1 - 2005:8, Ito and Sato (2006) examined the passthrough effects of exchange rate changes on the domestic prices in the East Asian economies. Their main results are as follows: (1) the degree of exchange rate pass-through to import prices was quite high in the crisis-hit economies; (2) the pass-through to consumer price index (CPI) was generally low, with the notable exception of Indonesia; and (3) in Indonesia both the impulse response of monetary policy variables to exchange rate shocks and that of CPI to monetary policy shocks are positive, large, and statistically significant. Thus, Indonesia's accommodative monetary policy, coupled with the high degree of the CPI's responsiveness to exchange rate changes was an important factor in the spiralling effects of domestic price inflation and sharp nominal exchange rate depreciation in the post-crisis period.

Aliyu, Yakub, Sanni, and Duke (2008) investigated, for the first time, the degree of exchange rate pass-through to import and consumer prices in Nigeria between 1986 $\mathrm{Pl}$ and 200704. They employed the vector error correction methodology (VECM) and found that exchange rate passthrough in Nigeria during the period under review was low, although slightly higher in the import than in the consumer prices, significant and persistent. A $1 \%$ shock to exchange rate, for instance, resulted in a $14.3 \%$ and $-10.5 \%$ pass-through effect to import and consumer prices four quarters ahead, respectively.

Still in Nigeria, Oyinlola (2009) examined the exchange rate pass-through to different measures of domestic price. Oyinlola used VECM that incorporates exchange rate, money supply, world export price, income and tariff rate on annual data from 1980-2008. The results revealed that that a long-run relationship existed between exchange rate and domestic price measured by CPI, and no evidence of the short-run impact of exchange rate on domestic price was recorded. Other factors such as money supply, world export price and income have a significant influence on the variations of all measures of domestic price in this study.

The lessons to be learnt from these studies are that there is evidence of exchange rate passthrough and the extent to which this occurs varies from country to country. Exchange rate passthrough has been found to be incomplete in many countries. However, it depends on the relative importance of the specific factors that determine the degree of exchange rate pass-through in a country. The particularly interesting issue here is that most of these studies are from developing countries and most of them are actually small open economies. Furthermore, some countries, like Namibia, practise a pegged or fixed exchange rate. To date the researcher is not aware of any study on Namibia that has specifically examined the extent of exchange pass-through. The only study that come close is that of Gaomab II (1998), which revealed that in the long run about $70 \%$ of increase in Namibia's prices is as a result of increases in South Africa's prices (S.A. prices used as a proxy for foreign prices in that particular study). There was no further exercise in this regard accumulating a lag of an additional 13 years of data and different experiences with regard to exchange rate changes and monetary policy now available in Namibia. This in itself is a good reason for renewed research on exchange rate pass-through in Namibia. Although Gaomab's study provides very useful insights on the pass-through in Namibia, there still remains a research question after Gaomab's study. The question is whether the same can be said after 13 years? Furthermore, what can be said about the exchange rate pass-through? 


\section{METHODOLOGICAL FRAMEWORK}

\subsection{Data Description}

In order to analyse the exchange rate-domestic price relationship, this study employs quarterly data series of the following variables: exchange rate $(S)$ captured by the nominal effective exchange rate (a fall in its value implies depreciation, while an increase is appreciation), domestic price (CP) captured by the CPI and foreign prices (CPSA) captured by South Africa's CPI. Data was sourced from Bank of Namibia and South Africa's Reserve Bank. The study covers the period 1993:01-2011:04

\subsection{Analytical Framework}

In order to examine a reinforcing mechanism between domestic prices and the exchange rate, a VAR analysis is considered appropriate for determining the exchange rate pass-through effect. Studies such as those of McCarthy (2000), Hahn (2003) and Faruqee (2004) used a VAR approach for an analysis of pass-through of several types of shocks to domestic inflation. In particular, the SVAR, a hybrid of the VAR, appears to have been widely used in empirical analysis for ERPT.

VAR is a system of dynamic linear equations where all the variables in the system are treated as endogenous. The reduced form of the system gives one equation for each variable, which specifies each variable as a function of the lagged values of their own and all other variables in the system. To draw the SVAR mainframe, it is assumed that Namibia's exchange rate passthrough process is described by a dynamic system whose structural form equation is given by:

$$
\mathrm{Ay}_{\mathrm{t}}=\Psi+\Omega_{1} y_{t-1}+\Omega_{2} y_{t-2}+\Omega_{p} y_{t-p}+B \mu_{t}
$$

where $A$ is an invertible $(n \times n)$ matrix describing contemporaneous relations among the variables; $y_{t}$ is an $(n \times 1)$ vector of endogenous variables such that; $y_{t}=\left(y_{1 t}, y_{2 t}, \ldots, y_{n t}\right)$; $\Psi$ is a vector of constants; $\Omega_{i}$ is an $(n \times n)$ matrix of coefficients of lagged endogenous variables $(\forall i=1,2,3 \ldots p) ; B$ is an $(n \times n)$ matrix whose non-zero off-diagonal elements allow for direct effects of some shocks on more than one endogenous variable in the system; and $\mu_{i}$ are uncorrelated or orthogonal white-noise structural disturbances i.e. the covariance matrix of $\mu_{i}$ is an identity matrix $E\left(u_{t}, \mu_{t}^{\prime}\right)=1$. Equation (1) can be rewritten in compact form as:

$$
\mathrm{Ay}_{\mathrm{t}}=\Psi+\Omega(\mathrm{L}) y_{t-i}+B \mu_{t}
$$

Where $\Omega(L)$ is a $(n \times n)$ finite order matrix polynomial in the lag operator $L$.

The vector of endogenous variables for the exchange rate pass-through is:

$$
Y_{t}=[C P S A, S, G Y, C P]
$$

with $G y$ denoting output growth, $C P$ the rate of inflation for Namibia, $S$ the nominal effective exchange rate and CPSA the rate of inflation for South Africa. The equation separating structural economic shocks from the estimated reduced form residuals for the exchange rate pass-through model is presented as: 


$$
\left[\begin{array}{cccc}
1 & 0 & 0 & 0 \\
a_{21} & 1 & 0 & 0 \\
a_{31} & 0 & 1 & 0 \\
a_{41} & 0 & 0 & 1
\end{array}\right]\left[\begin{array}{c}
\varepsilon_{t}^{C P S A} \\
\varepsilon_{t}^{S} \\
\varepsilon_{t}^{G Y} \\
\varepsilon_{t}^{C P}
\end{array}\right]=\left[\begin{array}{cccc}
b_{11} & 0 & 0 & 0 \\
0 & b_{22} & 0 & 0 \\
0 & 0 & b_{33} & 0 \\
0 & 0 & 0 & b_{44}
\end{array}\right]\left[\begin{array}{c}
\mu_{t}^{C P S A} \\
\mu_{t}^{S} \\
\mu_{t}^{G Y} \\
\mu_{t}^{C P}
\end{array}\right]
$$

One notable thing is that Namibia is a highly import-dependent country, which is why for foreign trading CPI, South Africa's CPI is used (Namibia imports more than $80 \%$ of its total imports from that country). Furthermore, to be consistent with the IMF, the NEER is defined as the index of foreign currency price per local currency. This is to capture the total effect of exchange rate changes in Namibia with other trading partners. In this regard, NEER is considered the appropriate measure instead of the bilateral exchange rate vis-à-vis the US dollar, as it is a norm with many other studies.

The main uses of the VAR model are the impulse response analysis, variance decomposition, and Granger causality tests. The analysis is carried out in the following order. The first step requires a test for the univariate characteristics of data. This is done by using some formal testing, namely, the Augmented Dickey-Fuller (ADF), Phillips-Perron (PP) and Kwiatkowski-PhillipsSchmidt-Shin (KPSS) tests are applied (Pindyck \& Rubinfeld, 1991; Gujarati, 1995; 2003 ). Thereafter, a Granger causality test is performed. This is to examine whether lagged values of one variable help to predict another variable (Stock \& Watson, 2001:104). The following step would be to conduct tests for cointegration, i.e. if two or more series have long-run equilibrium. The Johansen cointegration test is used to determine the number of cointegration relations for forecasting and hypothesis testing. There are many steps that must be followed before applying the Johansen test. First it is necessary to determine the number of lags, since this has a big effect in the analysis. There are five criteria: the sequential likelihood ratio (LR), Akaike information criterion (AIC), Schwarz information criterion (SC), final prediction error (FPE) and Hannan Quinn information criterion (HQ).

If cointegration is found among the variables, the adjustment of the short-run to the long-run equilibrium is obtained through the vector error correction model (VECM), and if no cointegration found then the VAR is estimated. In empirical applications, the main use of the VAR is the impulse response function, which traces the response of the endogenous variables to one standard deviation shock or change to one of the disturbance terms in the system. Variance decomposition is an alternative method to the impulse response functions for examining the effects of shocks to the dependent variables. This technique determines how much of the forecast error variance for any variable in a system is explained by innovations to each explanatory variable, over a series of time horizons (Stock \& Watson, 2001:106).

\section{EMPIRICAL ANALYSIS AND RESULTS}

This section presents the detailed empirical analysis and results of the study. This study also briefly reports the results from cointegration, Granger causality tests, impulse responses and forecast error variance decompositions.

\subsection{Testing for stationarity}

In testing for stationarity the Augmented Dickey-Fuller tests were used. The study concedes that the ADF statistic has limitations because it has low power-meaning it tends to under-reject the 
null hypothesis of unit roots. To address this limitation additional test statistics such as the Phillips-Perron (PP) and the Kwiatkowski-Phillips-Schmidt-Shin (KPSS) were also used. The results of unit root test in level form and first difference are presented in TABLE 1.

The series were found to be non-stationary in level form; hence the hypothesis of the presence of unit root can be accepted, and it can be concluded that all variables are non-stationary in level form with the exception of InCPSA according to the ADF. Since the other two statistical tests are contrary to the ADF, the majority rule was followed; hence one can conclude that all the test statistics concluded that all the four variables are non-stationary. The next step is then to difference them once as shown in TABLE 1 . After differentiating the variables once, all the test statistics showed that the series are now stationary at all levels of significance, rejecting the hypothesis of unit root at $1 \%, 5 \%$ and $10 \%$. Thus, at all levels of significance the hypothesis of unit root is rejected, and, therefore, it can be concluded that the variables are all stationary at first difference - in other words, the variables are integrated of order one.

\subsection{Cointegration test}

Cointegration mimics a long-run relation between the variables. The results for cointegration test for the ERPT model indicates that there is one cointegrating equation. This is confirmed by both the trace and maximum Eigen values test statistics, as shown in TABLE 2. The number of lag lengths has been determined as shown in TABLE 3 in the appendix.

TABLE 2: Johansen Cointegration Test Based on Trace and Maximum Eigen Values of the Stochastic Matrix for the exchange rate pass-through model

\begin{tabular}{ccccccccc}
\hline \multicolumn{3}{c}{ Maximum Eigen Test } \\
H:rank $=r$ & H: rank $=r$ & Statistic & $\begin{array}{c}95 \% \\
\text { Critical Value }\end{array}$ & H: rank $=r$ & H: rank =r & Statistic & $\begin{array}{c}95 \% \\
\text { Critical Value }\end{array}$ \\
\hline$r=0$ & $r=1$ & 37.64 & 27.58 & $r=0$ & $r>=1$ & 59.39 & 47.86 \\
$r<=1$ & $r=2$ & 16.52 & 21.13 & $r<=1$ & $r>=2$ & 21.74 & 29.80 \\
$r<=2$ & $r=3$ & 4.73 & 14.26 & $r<=2$ & $r>=3$ & 5.22 & 15.49 \\
$r<=3$ & $r=4$ & 0.49 & 3.84 & $r<=3$ & $r>=4$ & 0.49 & 3.84 \\
\hline
\end{tabular}

Source: Authors' computations

Notes: Both Max-eigenvalue and Trace tests indicates 1 cointegrating equation at the 0.05 level. Sample period 1993:01 to 2011:04.

\subsection{Granger Causality}

The results of the Granger causality test for the four-variable VAR are presented in TABLE 4. The results show that the exchange rate can help to predict consumer prices. However, all the other variables do not help to predict one another, i.e. there is no causality among the rest of the variables. 


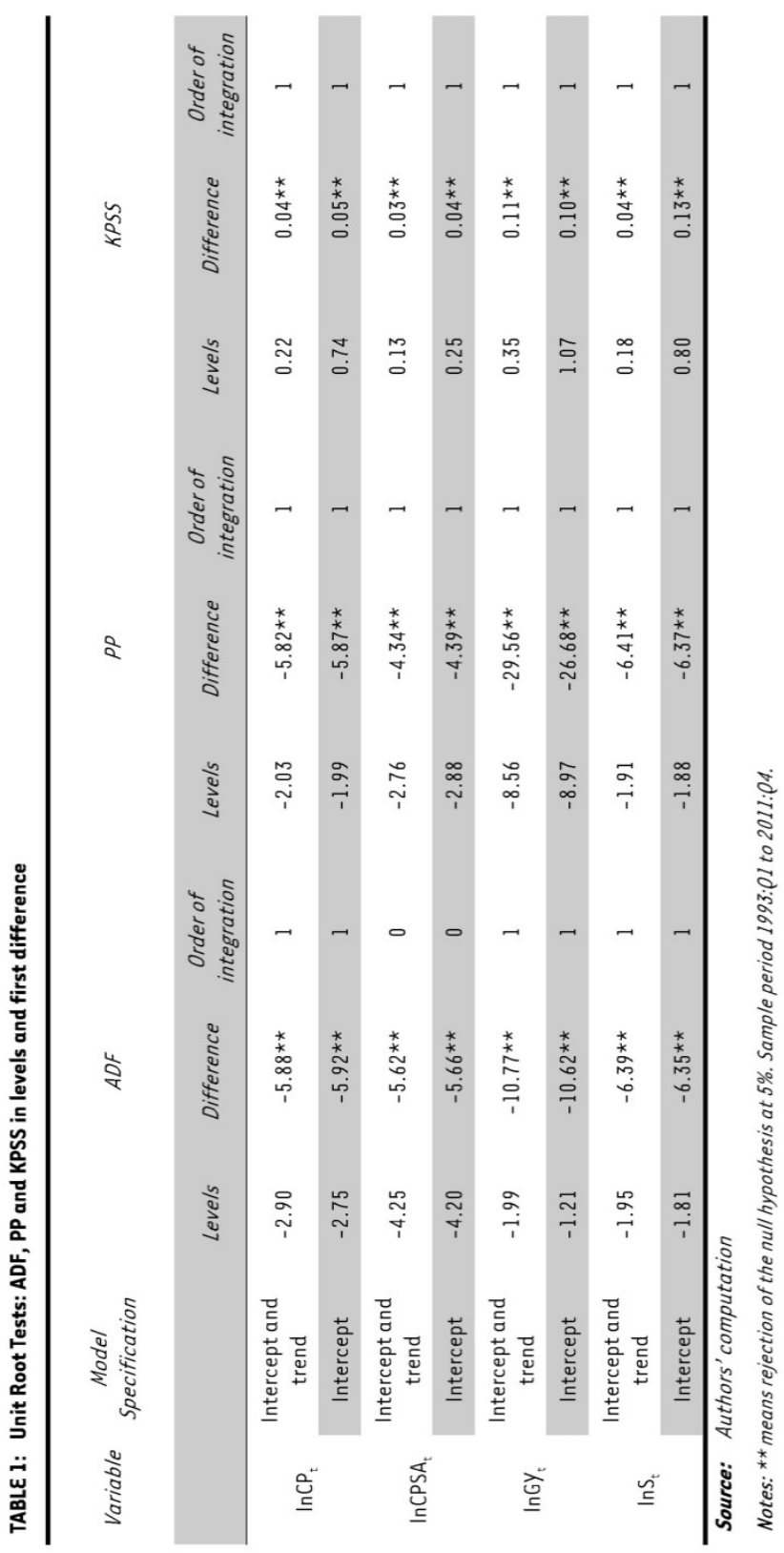


TABLE 4: Granger causality tests for exchange rate pass-through

\begin{tabular}{|c|c|c|c|c|}
\hline \multicolumn{5}{|c|}{ Dependent Variable in Regression } \\
\hline Regressor & CPSA & $S$ & Gy & $C P$ \\
\hline CPSA & 0.00 & 0.50 & 0.60 & 0.40 \\
\hline S & 1.7 & 0.00 & 0.72 & $0.00 * \star$ \\
\hline Gy & 0.06 & 0.42 & 0.00 & 0.40 \\
\hline$C P$ & 0.57 & 0.71 & 0.95 & 0.00 \\
\hline
\end{tabular}

Source: Authors' computations

Notes: a) CPSA denotes the inflation rate for South Africa, NS denotes exchange rate, GY denotes output and $C P$ denotes rate of price inflation.

b) $* *$ means rejection of the null hypothesis at $5 \%$

The results on whether VAR satisfies the stability condition are presented in TABLE 5 , while the results for the diagnostic test are presented in TABLE 6 in the appendix.

\subsection{Impulse Response Function}

FIGURE 1 plots the impulse responses for consumer prices to one standard deviation shock on the exchange rate change. The vertical axes report the approximate percentage change in domestic prices in response to a $1 \%$ shock in exchange rate. An increase in exchange rate reflects an appreciation. In response to one standard deviation shock on the exchange rate (in the form of appreciation), the price level index exhibits a continuous decline at least over 10 quarters. The plot seems to suggest that the shock to the exchange rate does contemporaneously affect the domestic price level in Namibia. This is contrary to the theoretically lagged effect from the exchange rate to domestic prices due to, among other factors, the pricing strategy by firms, the dynamics of demand response, and payment lags.

Given the fact that the variables are cointegrated, it is expected that the shock to the exchange rate will lead to a deviation of the price level from its equilibrium in Namibia for only a short period of time, after which the rates are expected to converge to their long-run levels as demonstrated in FIGURE 1 . There appear to be price transitory effects after two quarters that start to stabilise thereafter, but far above the baseline or far from the steady-state. In general, the analysis of the impulse responses suggests a significant and long-lasting effect from changes in exchange rates to inflation in Namibia, or high ERPT into domestic inflation. 


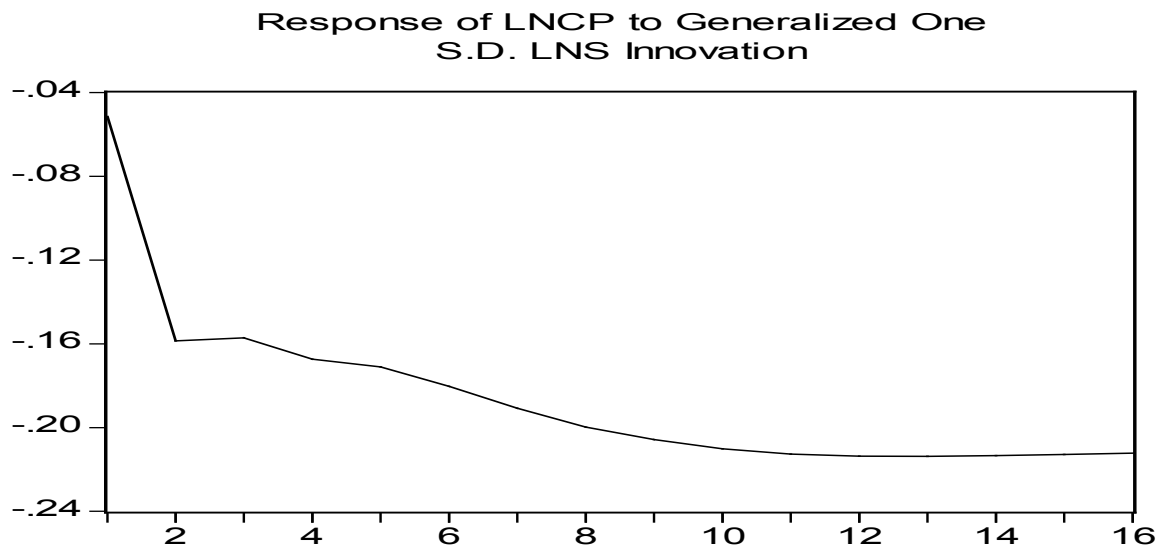

FIGURE 1: Impulse responses to exchange rate shocks: The exchange rate pass-through

Source: Author

TABLE 7 shows the results of the variance decomposition of the price level. The results demonstrate that the variations in the ERM are mostly explained by its own innovations in Namibia. Shocks to the exchange rate explain around one quarter or more of the movements in the price level and increase with time forecast. This result is comparable to the one reported by McCarthy (1999), who used the VAR model to investigate the ERPT in a set of nine industrialised countries. From his variance decomposition analysis, McCarthy found changes in the exchange rate to account for about 5 to 30 per cent of the variations in consumer prices. Another study by Al Yahyaei (2011) on the relevance of the US dollar peg to the economies of the Gulf Cooperation Council countries reported the same results. Such results imply that shocks to the exchange rate are partly responsible for explaining the forecast error variance of the price level. They also reflect that changes in the price level evolve endogenously with changes in the exchange rate, confirming the earlier findings of this article regarding the significant effect of the exchange rate variable, though incomplete, on the former variable.

\subsection{Forecast Error Variance Decomposition}

TABLE 7: Variance decomposition for the exchange rate pass-through

\begin{tabular}{lcccc}
\hline \multicolumn{4}{c}{ Variance Decomposition of CP } \\
Puarter & CPSA & $S$ & Gy & CP \\
\hline 1 & 18.090 & 2.133 & 0.255 & 79.522 \\
4 & 14.449 & 19.424 & 0.151 & 65.975 \\
8 & 14.372 & 25.220 & 0.133 & 60.275 \\
12 & 14.279 & 29.059 & 0.148 & 56.514 \\
16 & 14.123 & 30.948 & 0.153 & 54.726 \\
\hline
\end{tabular}

Source: Authors' computations 
Empirical analysis has illustrated that there is evidence of incomplete pass-through. A number of reasons from the vast theoretical literature on the pass-through of exchange rate can be cited in order to explain the incomplete pass-through and the failure of the PPP theory in Namibia. The most common reason is that incomplete pass-through could be attributed to the low share of traded goods in the CPI baskets for Namibia. The share of imported goods is considerably large in Namibia's GDP, but this share could be modest as compared to the weight of non-tradables.

A further reason could be that the presence of relatively modern financial markets in Namibia have allowed importers in to cover their profit and consequently consumer prices from fluctuation in exchange rates through hedging contracts. Moreover, the composition of a nation's imports is also crucial in determining the extent of the pass-through - for example, moving away from importing raw materials and towards the manufacturing sectors.

The monetary environment for Namibia could also have played another significant role in lowering the pass-through from exchange rate to inflation. For example, an inflationary expectation through depreciation of effective exchange rates in the Namibian dollar is believed to have been anchored by the pegged exchange rate regime.

\section{CONCLUSION}

This article attempted to develop and establish the nature of the link between changes in exchange rate and inflation in Namibia. This study employed the technique of structural vector autoregressive modelling, where the impulse response functions and forecast error decompositions were derived. The estimated results from both models have confirmed the relationship between movements in exchange rate and inflation in Namibia. To be specific, the results of the IRF suggest a significant and long-lasting effect from changes in exchange rates to inflation in Namibia. Changes in the price level evolve endogenously with changes in the exchange rate, confirming the earlier findings above regarding the significant effect of the exchange rate variable, though incomplete. The results also confirm the incomplete passthrough, indicating that the PPP theory does not hold, with regard to the price level, in the context of Namibia. The increasing long-run pass-through in Namibia can be attributed to many factors, including the degree of openness of the Namibian economy. Given the current exchange rate regime, namely, the pegged system for Namibia, and considering the current conditions of the Namibian economy, the monetary authority can effect actions such as partial monetary policy (required reserve, credit controls, and open market operations), containing domestic demand and addressing supply bottlenecks in order to allow the Namibian economy to maintain low impact from the external side on domestic prices and to generally control rising inflation.

\section{LIST OF REFERENCES}

Aliyu, S.U.R., Yakub, M.U., Sanni, G.K. \& Duke, 0.0. (2008). Exchange Rate Pass-through in Nigeria: Evidence from a Vector Error Correction Model.

Alper, K. (2003). Exchange Rate Pass-through Exchange Rate through Domestic Prices in Turkish Economy. Unpublished thesis. Middle East Technical University. 
Asteriou, D. \& Hall, S.G. (2009). Applied Econometrics: A Modern Approach, Revised Edition. New York: Palgrave Macmillan.

Baldwin, R. (1988). Hysterisis in Import Prices: The Beachhead Effect. The American Economic Review, 78, pp. 773-785.

Baldwin, R. \& Krugman P. (1989). Persistent Trade Effects of Large Exchange Rate Shocks. Quarterly Journal of Economics, 104, pp. 635- 654.

Bank of Namibia Annual Report. (1996). Bank of Namibia. Windhoek.

Bank of Namibia Annual Report. (2002). Bank of Namibia. Windhoek.

Bank of Namibia Annual Report. (2008). Bank of Namibia. Windhoek.

BON. (2008). Namibia's Monetary Policy Framework. Windhoek.

Bank of Namibia Quarterly Bulletins. (1996). Bank of Namibia. Windhoek.

Bank of Namibia Quarterly Bulletins. (2002). Bank of Namibia. Windhoek.

Bank of Namibia Quarterly Bulletins. (2006). Bank of Namibia. Windhoek.

Bank of Namibia Quarterly Bulletins. (2008). Bank of Namibia. Windhoek.

Bank of Namibia Quarterly Bulletins. (2010). Bank of Namibia. Windhoek.

Choudhri, \&. \& Hakura, D. (2006). Exchange rate pass-through to domestic prices: Does the inflationary environment matter? Journal of International Money and Finance 25, pp. 614-639.

Dornbusch, R. (1987). Exchange Rates and Prices. American Economic Review, 77, pp. 93-106.

Eckstein, Z. \& Soffer, Y. (2008). Exchange rate pass-through implications for monetary policy: the Israeli case. BIS Papers No 35.

Engle, R.F. \& Granger, C.W.J. (1987). Cointegration and Error Correction: Representation, Estimation and Testing, Econometrica, 49, pp. 1057-1072.

Engel, C. (2002). The Responsiveness Of Consumer Prices To Exchange Rates And The Implications For Exchange Rate Policy: A Survey Of A Few Recent New Open Economy Macro Models. National Bureau of Economic Research (Working Paper No. 8725).

Faruqee, H. (2004). Exchange Rate Pass-Through in the Euro Area: The Role of Asymmetric Pricing Behavior. International Monetary Fund. (Working Paper No. 04/14).

Gagnon, J. \& Ihrig, J. (2004). Monetary Policy and Exchange Rate Pass-through. International Journal of Finance and Economics, 9(4), pp. 315-338.

Gaomab, M. (1998). Modelling Inflation in Namibia. Bank of Namibia. (Occasional Paper).

Goldberg, P.K., \& Knetter, M.M. (1997). Good Prices and Exchange Rates: What have we learned. Journal of Economic Literature, 35(3), pp. 1243-1272.

Gujarati, D.N. (1995). Basic Econometrics. New York: McGraw-Hill.

Gujarati D. (2003). Basic Econometrics, $4^{\text {th }}$ edition. New York: McGraw Hill.

Ito, T. \& Sato, K. (2006). Exchange Rate Changes and Inflation in Post-Crisis Asian Economies: VAR Analysis of the Exchange Rate Pass-Through. NBER (Working Paper No. 12395).

Johansen, S. \& Juselius, K. (1990). Maximum Likelihood Estimation and Inference on Cointegration. With Applications to the Demand for Money. University of Oxford Journal, 52(2), pp. 169-210. 
Kim, K.H. (1998). US inflation and the dollar exchange rate: A vector error correction model. Applied Economics, 30(5), pp. 613-619.

McCarthy, J. (2000). Pass-Through of Exchange Rates and Import Prices to Domestic Inflation in Some Industrialized Economies. Bank for International Settlements, Basel. (Working Paper No. 79).

McFarlane, L. (2002). Consumer Price Inflation and Exchange Rate Pass-Through in Jamaica. Bank of Jamaica

Menon, J. (1994). Flexible Exchange Rates And Traded Goods Prices: A Theory of The Short Run. Center of Policy Studies, Monash University. (General Paper No. G-108).

Obstfeld, M. \& Kenneth, R. (1996). Foundation of International Macroeconomics. Massachusetts: MIT Press.

Oyinlola, M.A. (2009). Exchange Rate Pass-Through to Domestic Prices in Nigeria: A Dynamic Investigation. Department of $\varepsilon$ conomics. University of Nigeria.

Pindyck, R.S. \& Rubinfeld, D.L. (1991). Econometric Models \& Economic Forecasts. London: McGrawHill, Inc.

Sahminan. (2002). Exchange Rate Pass-Through into Import Prices: Empirical Evidences from Some Southeast Asian Countries. The University of North Carolina at Chapel Hill.

Taylor, J. (2000). Low Inflation, Pass-Through and the Pricing Power of Firms. European Economic Review, 44, pp. 1389-1408.

Wimalasuriya, S.M. (2005). Exchange Rate Pass-Through: To What Extent do Prices Change in Sri Lanka. Central Bank of Sri Lanka Staff Studies - Volume 37 Numbers $1 \& 2$. 